\title{
Design Of Battery Charge Control System On Hybrid Power Plants
}

\author{
Richard Semuel Waremra ${ }^{1, *}$ \\ ${ }^{1}$ Department of Physics Education, Faculty of Teacher Training and Education, Musamus University, Merauke - Indonesia
}

\begin{abstract}
Battery charge control system has been built on hybrid power plants. The source of voltage comes from horizontal-axis windmill with 500 Watt power, Monocrystalline solar cell with 200 WP for charging 12 Volt $35 \mathrm{AH}$. The aim of this research is to optimize battery charging process using potential energy sources from wind and solar. Control system on hybrid power plant is done by adjusting the amount of voltage or electric current based on the need of the battery charging. The making of the control system uses several software and hardware. Some of the main components used are ATMega 16 micro-controller and voltage censor. The control system that has been made is tested by monitoring the voltage and current during the control process. The test result shows that the control system that has been made is able to work properly in controlling the input voltage from the source and charger voltage on the battery.
\end{abstract}

Keywords: hybrid system, control system, battery

\section{Introduction}

Windmill is one of the potential alternatives to meet the need of energy, especially in archipelagic areas with sufficient wind potential. Moreover, solar cell is one of the environmental-friendly and promising energies in the future due to its absence of pollution during energy conversion process, and the source of the energy is widely provided by nature, that is, sunlight $[1,2]$.

Hybrid energy system that combines multiple energy sources to supply electrical energy to the load for maximizing energy at low cost, pollution-free, and excellent power quality, and sustainable energy[3]. The existing control system has a working system that controls the battery charging up to the full condition. After the condition is reached, the control system cut the source energy for the battery charging[3,4]. Therefore, it is necessary to use control system that is able to solve the problem. One of the efficient control systems is to make automatic charger controller tools that optimize energy potential from wind and solar energy for battery charging.

\section{Methodology}

The design of battery charging control system on hybrid power plant consists of three big parts, namely input variable, control system, and output variable. Input variable from windmill and solar cell is monitored by using voltage censor, while control system is monitored by using multiple hardware circuits such as regulator circuit, charger circuit, and voltage censor circuit. Output variable consists of 5 relays controlled using ATMega 16 micro-controller for battery charging process and ON/OFF process to the load. The configuration of control system build is seen in the form of block diagram on the picture below.

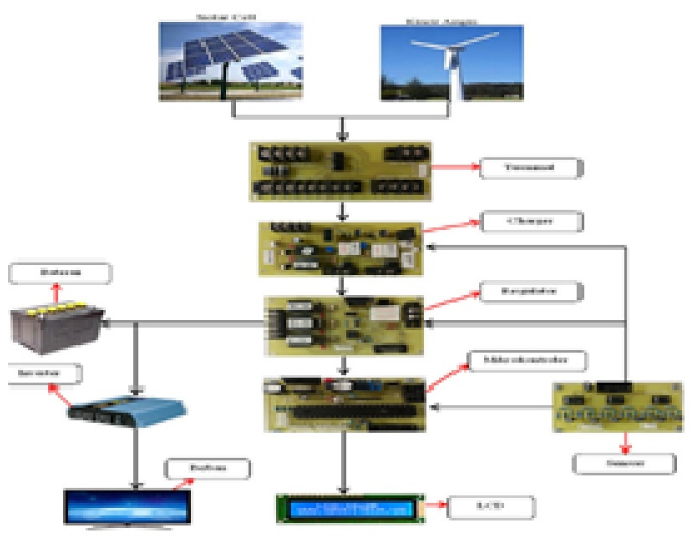

Fig. 1. The overall diagram block of the control system of hybrid power plant.

\section{Results And Discussion}

The design of battery charging control system is built on hybrid power plant. Control system has been built in three steps, that is, hardware design, software design, 
and equipment test. The hardware design consists of one-source terminal and two-source terminal design, voltage censor design, charger circuit design, microcontroller circuit design, regulator design, and panel control box design. The software design is in the form of control system design using vision code AVR realized with $\mathrm{C}$ language. The control system test is conducted by collecting monitoring data and observing the work process of the control system during charging.
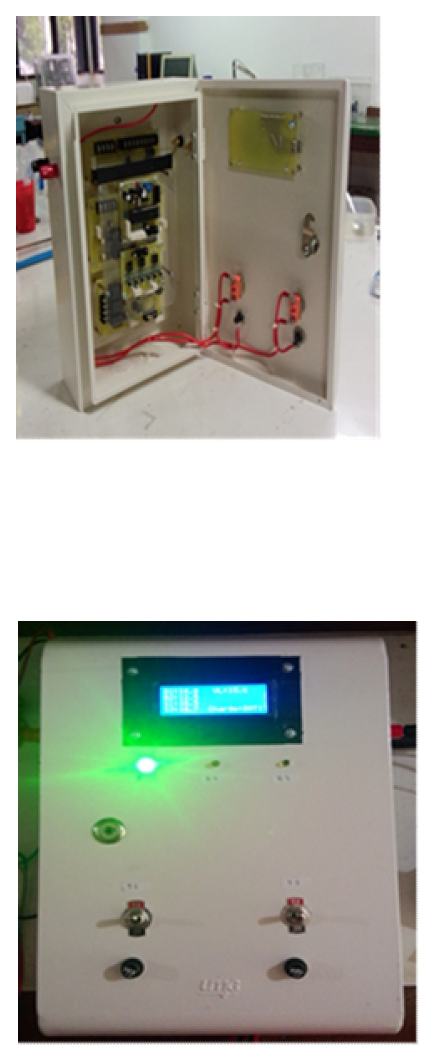

Fig. 2. Hybrid Control System.

Control system performance for battery charging is tested by monitoring and controlling the built battery charging system. The test is performed by testing all of the control systems built including hardware and software. The built system will monitor input voltage of two sources, that is, solar cell and windmill along with the work process of the control system. Monitoring test consists of the source voltage, load voltage, voltage in each battery and current done by the censor. Meanwhile, the performance of the software for the control process is carried out by monitoring the control system that occurs due to interruption based on the program specified.
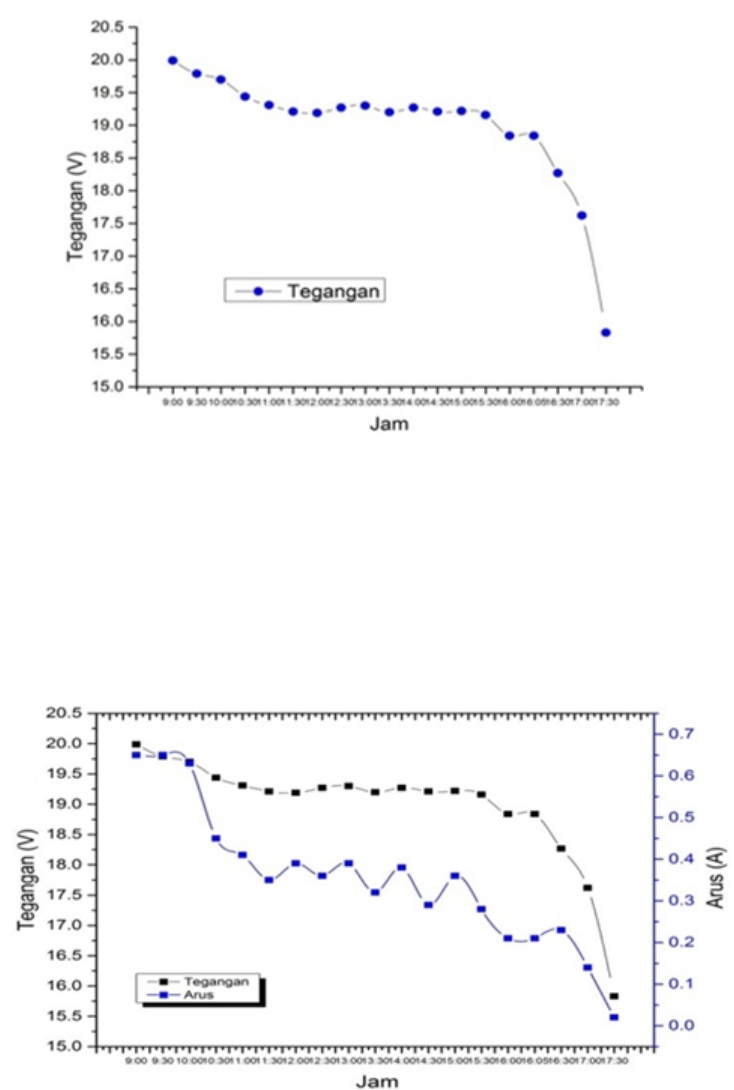

Fig. 3. ( a ) Test Result of Solar Cell Source ( b ) . Test Result of Solar Cell Source using load

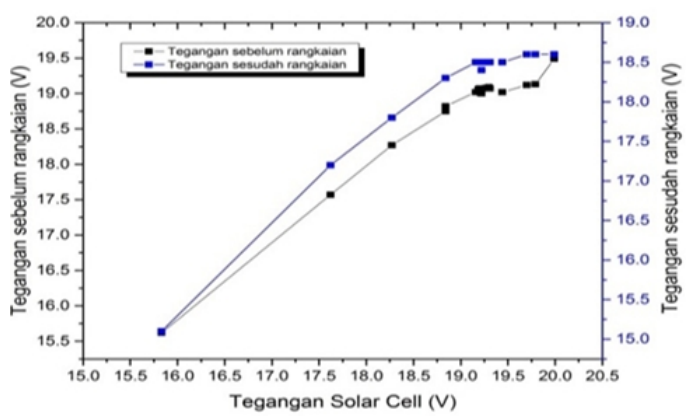




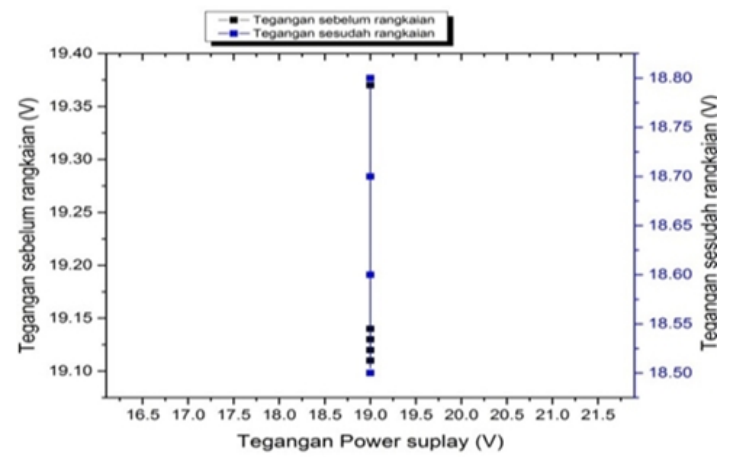

Fig. 4. (a) Test Result of Voltage Before and After Circuits from Solar Cell Source (b) Test Result of Voltage Before and After Circuits from Solar Cell Source Power Supply Source
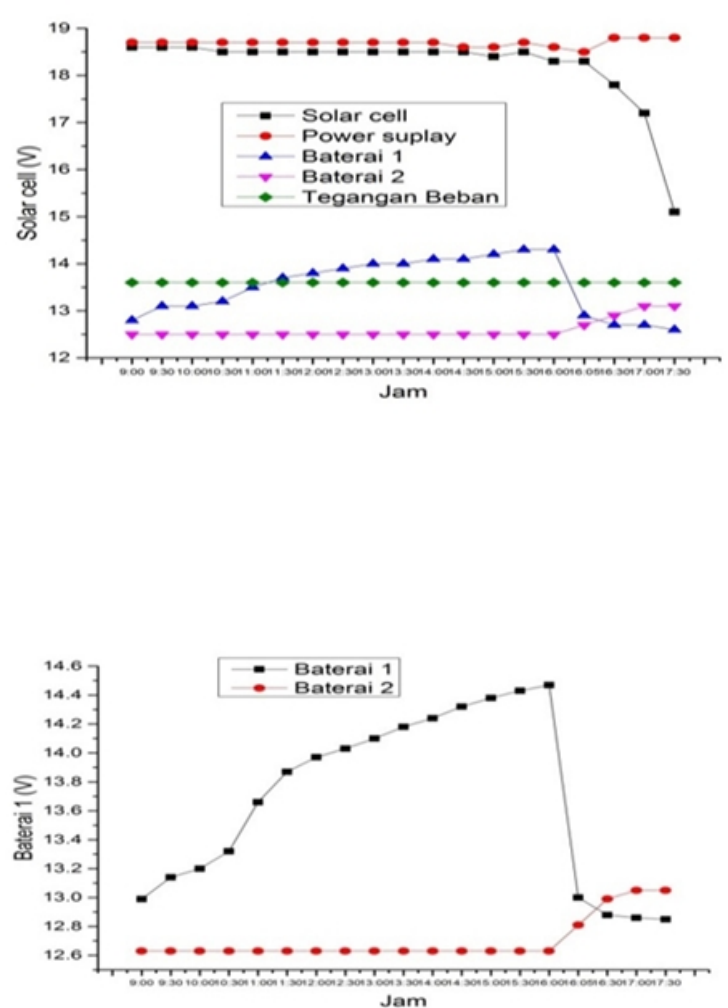

Fig. 5. (a) Test Result of LCD Display (b) Result of Direct Battery Measurement
Control system test of battery charging on the picture above shows that there is voltage and current change during the control process. In this test result, voltage distribution from the solar cell source during the control process is on the voltage range of 19.79 volt at 9:00 a.m. and voltage of 19.30 volt at 1:00 p.m. On the graph of solar cell test, it can be observed that the voltage distribution in the afternoon increases from 9:00 a.m. to 2:30 p.m. caused by the effect of solar heat, while voltage supply power source used is constant, that is, 19.00 volt. The source voltage monitoring during the control process has significant change during the battery charging and loading process after being connected to the control circuit, and source voltage of solar cell before and after circuit experience voltage drop. The result of monitoring and control process obtained also shows that when the source voltage condition is met, then the control process of charging occurs. Charging time for battery with capacity of 12 Volt 35 Ah for two batteries, in which battery one and two is reconditioned empty, is the charging time battery one starts from 9:00 a.m. to 4.05 p.m. After the first battery is full, the second battery is automatically charged, and the first battery is connected to the load. The measurement of battery voltage displayed on LCD and direct measurement experiences voltage difference.

\section{References}

1. Dipl. Kulturwirt, Gunnar Braun. The Potential of Wind Power as a Renewable Energy Source for Indonesia. July 2002. University of Passau, Department of Southeast Asian Studies.

2. Agar, David, 2005, "A Description of Current Technology in Solar Cell", Department of Physical Chemistry, University of Jyvaskyla.

3. Hankins, Mark. 2010. Stand-Alone Solar Electric Systems. London: Earthscan.

4. Gustave Paul Corten,dkk, 8 september 1968

5. Papadopoulou, Elena V.M. 2011. Photovoltaic Industrial Systems. Berlin: Springer.

6. Bejo, A, (2008), "Rahasia Kemudahan Bahasa C Dalam Mikrokontroler ATMega8535”, Edisi Pertama, Graha Ilmu, Yogyakarta.

7. sumber : suprianto blog's 2011

8. Hamada, M., 2008., AIST makes LiFePO4 Superfine Particles For Li Ion Baterry, Nikkei Automotive Technology, Japan. 